\title{
Disadvantages of publishing biomedical research articles in English for non-native speakers of English
}

\author{
Mohsen Rezaeian \\ Social Medicine Department, Occupational Environmental Research Center, Rafsanjan Medical School, Rafsanjan University of Medical \\ Sciences, Rafsanjan, Iran
}

OBJECTIVES: English has become the most frequently used language for scientific communication in the biomedical field. Therefore, scholars from all over the world try to publish their findings in English. This trend has a number of advantages, along with several disadvantages.

METHODS: In the current article, the most important disadvantages of publishing biomedical research articles in English for non-native speakers of English are reviewed.

RESULTS: The most important disadvantages of publishing biomedical research articles in English for non-native speakers may include: Overlooking, either unintentionally or even deliberately, the most important local health problems; failure to carry out groundbreaking research due to limited medical research budgets; violating generally accepted codes of publication ethics and committing research misconduct and publications in open-access scam/predatory journals rather than prestigious journals.

CONCLUSIONS: The above mentioned disadvantages could eventually result in academic establishments becoming irresponsible or, even worse, corrupt. In order to avoid this, scientists, scientific organizations, academic institutions, and scientific associations all over the world should design and implement a wider range of collaborative and comprehensive plans.

KEY WORDS: Biomedical research, Medical writing, English language, Disadvantages

\section{INTRODUCTION}

English has become the most frequently used language for scientific communication in the biomedical field. Evidence suggests that a constantly increasing trend for English to predominate in biomedical publications may have begun in approximately 1900 [1], and this trend has a number of advantages [2]. For

Correspondence: Mohsen Rezaeian

Social Medicine Department, Occupational Environmental Research Center, Rafsanjan Medical School, Rafsanjan University of Medical Sciences, Rafsanjan 7717735959, Iran

Tel: +98-3915234003, Fax: +98-3915225209

E-mail: moeygmr2@yahoo.co.uk

Received: Apr 20, 2015, Accepted: May 1, 2015, Published: May 1, 2015

This article is available from: http://e-epih.org/

(C) 2015, Korean Society of Epidemiology

(C) This is an open-access article distributed under the terms of the Creative Commons Attribution License (http://creativecommons.org/licenses/by/3.0/), which permits unrestricted use, distribution, and reproduction in any medium, provided the original work is properly cited. example, publishing in English not only helps to communicate scientific findings more easily, but also it makes scientific findings more widely accessible and therefore more likely to be cited. Furthermore, English is a living language, meaning that it contains prefixes, suffixes, and other word-building elements that enable the logical construction of new words.

These factors explain why scholars in most developed and developing countries where the mother tongue is not English have a tendency to publish their findings in English [3,4]. Moreover, universities in such countries encourage this tendency by preferentially promoting faculty members who have publication records in prestigious English-language journals.

This trend unfortunately also has many disadvantages, which need to be dealt with very carefully and delicately by scientific communities all over the world. Otherwise, the disadvantages of this trend might eventually outweigh its advantages, resulting in the academic establishment becoming irresponsible or, even worse, corrupt, especially in developing countries where the mother tongue is not English. Therefore, in this piece, I will focus 
on the most important disadvantages of this trend, especially in medical research, and provide some suggestions of how to avoid or mitigate those disadvantages.

\section{DISADVANTAGES}

One of the most important disadvantages of this trend is that scholars in developing countries where English is not the mother tongue might overlook, either unintentionally or even deliberately, the most important local health problems. Such problems might be overlooked either because they are not suitable for publication in prestigious international English-language journals or because the authors fail to convince the editors and/or reviewers of these journals of the importance of such issues. As a result, in countries with a higher burden of some important but neglected local issues such as poverty, malnutrition, and infectious diseases [5-7], or other issues that negatively impact public health, such as natural or man-made disasters [8-11], fewer research projects are carried out in response to these problems.

This dynamic might result in the academic establishment in these countries becoming irresponsible. A previous study has shown that, despite an increasing quantity of publications on health policy and systems research in low-income countries, only $4 \%$ of these publications had a first author from the countries in question. Moreover, the capacity for conducting local research has not sufficiently increased in low-income countries [12].

The second most important disadvantage is likewise related to limited budgetary support for medical research. Due to budget shortages, scholars in developing non-English-speaking countries are not able to carry out groundbreaking research, even on issues that are relevant for publication in prestigious international journals. Therefore, they have a low rate of publication within prestigious medical journals [13].

The third most important disadvantage is that academic English writing is very difficult for many non-English-speaking scholars [14]. The most important reason for this is that one cannot directly translate from another language into English. Certain accepted terms exist for a range of concepts and the incorrect use of such terms can alter the meaning, many rules have extensive exceptions that can only be learned through rote memorization, several difficulties exist in tense usage, and various words have different meanings depending on the context. It has been established that research funding and English proficiency are strongly related to publication in the top-ranked general medical journals [15].

Furthermore, a number of non-English-speaking scholars, especially from developing countries, are also unfamiliar with some critical issues in publication ethics. The most important reasons for this are that publication ethics is not usually taught in universities and that few or no governing bodies are in place [16]. Therefore, some non-English-speaking scholars might innocently or deliberately violate generally accepted codes of publication ethics and commit research misconduct, such as failing to disclose all conflicts of interest, committing plagiarism, or, even worse, engaging in salami publication, publishing duplicate publications, or engaging in data fabrication or falsification [17].

These dynamics might result in the academic establishment in these countries becoming corrupt. A study investigating the retraction of publications in MEDLINE from 1966 to 2008 for plagiarism demonstrated that the retraction rate was higher among first authors affiliated with lower-income non-English-speaking countries [18].

Table 1. Summary table of problems and suggestions associated with the current system of English-language academic publication

\begin{tabular}{|c|c|}
\hline Problems & Suggestions \\
\hline Limited medical research budgets & $\begin{array}{l}\text { Allocating adequate budgetary resources for medical research and carrying out } \\
\text { collaborative research }\end{array}$ \\
\hline Overlooking the most important local health problems & $\begin{array}{l}\text { Allocating adequate health research budgets and carrying out collaborative } \\
\text { research }\end{array}$ \\
\hline Low record of publicationin prestigious medical journals & $\begin{array}{l}\text { Allocating adequate budgetary resources for medical research, carrying out } \\
\text { collaborative research, and selecting more scholars from developing countries } \\
\text { to serve as the editors and associate editors of prestigious health journals }\end{array}$ \\
\hline Unfamiliarity with academic English writing & $\begin{array}{l}\text { Implementing English-language writing courses, using self-employed science } \\
\text { editors, and providing affordable English-language editing services }\end{array}$ \\
\hline Unfamiliarity with some critical issues in publication ethics & $\begin{array}{l}\text { Urging scholars to use relevant publication guidelines, implementing appropriate } \\
\text { research methodologies courses, and carrying out collaborative research }\end{array}$ \\
\hline Publications in open-access scam/predatory journals & $\begin{array}{l}\text { Detecting and publicizing open-access scam/predatory journals, and waiving } \\
\text { publication charges in prestigious open-access journals }\end{array}$ \\
\hline $\begin{array}{l}\text { Lack of academic publishing platforms, lack of up-to-date skills and } \\
\text { techniques, lack of comprehensive public health databases, inade- } \\
\text { quate information-seeking behavior, inadequate capacity for teamwork }\end{array}$ & $\begin{array}{l}\text { Investment in biomedical research infrastructure, allocating adequate budgetary } \\
\text { resources for medical research, carrying out collaborative research, and imple- } \\
\text { menting appropriate research methodologies courses }\end{array}$ \\
\hline
\end{tabular}


There are a number of other fundamental problems which, taken together, create a constellation of disadvantages in the current system of academic publishing. Problematic dynamics that exacerbate this situation include the lack of academic publishing platforms, the lack of up-to-date skills and techniques, the lack of comprehensive public health databases, inadequate information-seeking behavior, an inadequate capacity for teamwork, and other similar problems (Table 1).

\section{SUGGESTIONS}

In my opinion, scientists, scientific organizations and associations, and academic institutions all over the world should think carefully about these disadvantages and try to overcome them through collaborative and comprehensive planning. For example, carrying out collaborative research between English-speaking scholars from developed countries and non-English-speaking scholars from developing countries is a well-established course of action. Although successful examples of such collaboration exist throughout the world [19-22], the current extent of such collaboration is not sufficient.

We should also think of other practical plans. For example, shifting more of the health research budgets of international organizations, such as the World Health Organization or non-governmental organizations, towards relevant health problems within developing countries could be considered. One of the prerequisites for allocating such budgetary funds should be that the work must be carried out collaboratively among Englishspeaking scholars from developed countries and non-Englishspeaking scholars from developing countries. Alternatively, international and non-governmental organizations could request non-English-speaking scholars to follow standard publication guidelines throughout the entire course of their research [23].

Moreover, prestigious international English language medical journals should implement a plan to select more editors or associate editors from developing countries in order to reflect their responsibility towards the health of all the people of the world [24]. In a sense, we are all living in a global village. Therefore, such journals should also consider including a section focusing on the publication, either in print or online, of well-conducted research that highlights relevant local and national health problems in the developing world.

Prestigious international English-language medical journals, especially those published by eminent publishers, should also adopt a new peer review policy in which it is not possible to reject a manuscript only because of weaknesses in academic English [25]. Instead, they should provide affordable English-language editing opportunities for worthwhile manuscripts that are submitted by non-English-speaking scholars. International organizations could potentially shift some of their research funding towards this important endeavor [26].

Similarly, a parallel policy should be adopted by the prestigious open-access medical journals. Moreover, they should discount or even waive their publication charges for well-researched manuscripts. Although such policies have been already put in place by some journals, which waive publication charges for authors in genuine financial hardship [27], such policies are not universal.

It is absolutely necessary to remember that most of the research which is carried out in non-English-speaking countries might receive dramatically less funding. For example, more than half of my research proposals have received less than US\$1,000 of funding. Therefore, it is simply impossible for scholars from these countries to pay up to US\$580 [28] for English-language editing and/or up to US\$2,900 [29] for publication charges.

In addition, scientists, scientific organizations, academic institutions, and scientific associations from all over the world, such as the World Association of Medical Editors, should also develop and implement a collaborative plan to detect open-access scam/predatory journals in the biomedical domain and publicize them, especially for non-English-speaking scholars [30].

Last but not least, some other practical suggestions would include conducting English-language writing courses for biomedical scholars all over the world, urging them to consult books and articles on English academic writing [31], and asking them to make use of self-employed science editors. Biomedical research organizations and universities, especially in non-Englishspeaking developing countries, could also employ experienced English editors [32].

The implementation of the above suggestions, along with investments in biomedical research infrastructure [33,34] and developing appropriate courses in research methodologies, may help overcome other problems that have been mentioned, such as the lack of academic publishing platforms, the lack of up-todate skills and techniques, the lack of comprehensive public health databases, inadequate information-seeking behavior, an inadequate capacity for teamwork, the inadequate appreciation of diverse types of research misconduct, and other problematic dynamics (Table 1).

\section{CONCLUSION}

Despite the advantages associated with non-English-speaking scholars publishing scientific findings in English, we should be aware of its disadvantages as well. These disadvantages could eventually result in academic establishments becoming irresponsible or, even worse, corrupt, especially in developing countries where the mother tongue is not English. In order to avoid this, 
scientists, scientific organizations, academic institutions, and scientific associations all over the world should design and implement a wider range of collaborative and comprehensive plans.

\section{ACKNOWLEDGEMENTS}

I would like to thank Lesley Pocock and two anonymous reviewers for their valuable comments on an earlier draft of this article.

\section{CONFLICT OF INTEREST}

The author has no conflicts of interest to declare for this study.

\section{REFERENCES}

1. Monge-Nájera J, Nielsen V. The countries and languages that dominate biological research at the beginning of the 21st century. Rev Biol Trop 2005;53:283-294.

2. Meneghini R, Packer AL. Is there science beyond English? Initiatives to increase the quality and visibility of non-English publications might help to break down language barriers in scientific communication. EMBO Rep 2007;8:112-116.

3. Waheed AA. Scientists turn to journals in English. ScientificWorldJournal 2001;1:239-240.

4. Butler D. French scientists turn to journals in English. Nature 2000; 405:500.

5. Satyanarayana K, Srivastava S. Poverty, health \& intellectual property rights with special reference to India. Indian J Med Res 2007;126: 390-406.

6. Blakely T, Hales S, Kieft C, Wilson N, Woodward A. The global distribution of risk factors by poverty level. Bull World Health Organ 2005;83:118-126.

7. Atinmo T, Mirmiran P, Oyewole OE, Belahsen R, Serra-Majem L. Breaking the poverty/malnutrition cycle in Africa and the Middle East. Nutr Rev 2009;67 Suppl 1:S40-S46.

8. McMahon MM. Disasters and poverty. Disaster Manag Response 2007;5:95-97.

9. Kim N. How much more exposed are the poor to natural disasters? Global and regional measurement. Disasters 2012;36:195-211.

10. Rezaeian M. Wars versus SARS: are epidemiological studies biased? Eur J Epidemiol 2014;29:453-454.

11. Rezaeian M. War epidemiology: an urgent plea. Epidemiology 2015; 26:e10-e11.

12. Adam T, Ahmad S, Bigdeli M, Ghaffar A, Røttingen JA. Trends in health policy and systems research over the past decade: still too little capacity in low-income countries. PLoS One 2011;6:e27263.

13. Soteriades ES, Falagas ME. A bibliometric analysis in the fields of preventive medicine, occupational and environmental medicine, epi- demiology, and public health. BMC Public Health 2006;6:301.

14. Vasconcelos SM, Sorenson MM, Leta J. Scientist-friendly policies for non-native English-speaking authors: timely and welcome. Braz J Med Biol Res 2007;40:743-747.

15. Man JP, Weinkauf JG, Tsang M, Sin DD. Why do some countries publish more than others? An international comparison of research funding, English proficiency and publication output in highly ranked general medical journals. Eur J Epidemiol 2004;19:811-817.

16. Ana J, Koehlmoos T, Smith R, Yan LL. Research misconduct in lowand middle-income countries. PLoS Med 2013;10:e1001315.

17. Rezaeian M. A review on the diverse types of research misconduct. World Fam Med J 2014; 12:43-44.

18. Stretton S, Bramich NJ, Keys JR, Monk JA, Ely JA, Haley C, et al. Publication misconduct and plagiarism retractions: a systematic, retrospective study. Curr Med Res Opin 2012;28:1575-1583.

19. Nchinda TC. Research capacity strengthening in the South. Soc Sci Med 2002;54:1699-1711.

20. Chandiwana S, Ornbjerg N. ChaReview of North-South and SouthSouth cooperation and conditions necessary to sustain research capability in developing countries. J Health Popul Nutr 2003;21:288-297.

21. Lansang MA, Dennis R. Building capacity in health research in the developing world. Bull World Health Organ 2004;82:764-770.

22. Macfarlane SB, Evans TG, Muli-Musiime FM, Prawl OL, So AD. Global health research and INCLEN. International Clinical Epidemiology Network. Lancet 1999;353:503.

23. Rezaeian M. The application of publication guidelines should extend to cover their designing stage and protocol writing. Ann Epidemiol 2013;23:815

24. Keiser J, Utzinger J, Tanner M, Singer BH. Representation of authors and editors from countries with different human development indexes in the leading literature on tropical medicine: survey of current evidence. BMJ 2004;328:1229-1232.

25. Rohra DK. Representation of less-developed countries in Pharmacology journals: an online survey of corresponding authors. BMC Med Res Methodol 2011;11:60.

26. Paton C, Househ M, Malik M. The challenges of publishing on health informatics in developing countries. Appl Clin Inform 2013;4:428433.

27. Mrak RE, Griffin WS. Funding free and universal access to Journal of Neuroinflammation. J Neuroinflammation 2004;1:19.

28. Editage by CACTUS. Pricing for editing services [cited 2015 Feb 27]. Available from: https://www.editage.com/pricing/.

29. PLOS. Publication fees [cited 2015 Feb 27]. Available from: http:// www.plos.org/publications/publication-fees/.

30. Butler D. Investigating journals: the dark side of publishing. Nature 2013;495:433-435.

31. Tychinin DN, Kamnev AA. Beyond style guides: suggestions for better scientific English. Acta Histochem 2005; 107:157-160.

32. Ludbrook J. Writing intelligible English prose for biomedical journals. Clin Exp Pharmacol Physiol 2007;34:508-514.

33. Peprah E, Wonkam A. Biomedical research, a tool to address the health issues that affect African populations. Global Health 2013;9:50.

34. Maher D, Sekajugo J, Harries AD, Grosskurth H. Research needs for an improved primary care response to chronic non-communicable diseases in Africa. Trop Med Int Health 2010;15:176-181. 